\title{
Study of Knowledge of Students about Zika Virus Fever Infection, Tail University, Saudi Arabia
}

\author{
Etemad A.A. El-Shereef ${ }^{1}$, Haneen Asaad Hammadi' ${ }^{2}$ Wateen Asaad Hammadi ${ }^{3}$ \\ ${ }^{1}$ Professor of Public Health and Community Medicine, Taif College of Medicine, KSA, and Assiut Faculty of Medicine, Egypt \\ ${ }^{2}$ Sixth year Medical student, Medical College, Taif University, KSA \\ ${ }^{3}$ Third Year Medical Students, Medical College, Taif University, KSA
}

\begin{abstract}
Zika virus is a member of the virus family Flaviviridae and the genus Flavivirus, transmitted by daytime-active Aedes mosquitoes, such as A. aegypti. This is a cross sectional study of knowledge of girls' students about zika virus infection in Taif University, Saudi Arabia. One hundred and thirty four (54.7\%) of medical students and 111 (45.3\%) of preparatory year students participated in the present study. The percent of knowledge was significantly higher among medical students as compared to Preparatory year students (47.0\% versus 20.7\%) (P=0.000). About one quarter of students $(24.9 \%)$ knew who is at risk of being infected. (29.1\%) of medical students and (19.8\%) of preparatory year students mentioned that anyone who lives in or travels to an area where Zika virus is found can get it from mosquito bites. About thirty-one percent mentioned to some extent how Zika infection is prevented. The percent was (37.3\%) among medical students and (24.3\%) among preparatory year students. The main mentioned points were mosquito control and not travelling to epidemic area. Because Zika virus outbreaks could cause additional burdens on all levels of the health care system, it is essential to improve and implement protocols and well established plans for the patient screening and treatment and increasing knowledge of medical workers.
\end{abstract}

Keywords: Zika virus, knowledge, students, Taif, KSA.

\section{Background}

Zika virus is a member of the virus family Flaviviridae and the genus Flavivirus, transmitted by daytime-active Aedes mosquitoes, such as A. aegypti. Its name comes from the Zika Forest of Uganda, where the virus was first isolated in 1947 (United States Center for Disease Control and Prevention $\{C D C\}, 2015){ }^{1}$

Zika virus is extent to people through mosquito bites. They favor to bite persons, and live inside and out-of-doors close to people. These are the same mosquitoes that spread dengue and chikungunya viruses. These mosquitoes naturally lay eggs in and close to standing water in things like buckets, bowls, animal dishes, flower pots and vases. Mosquitoes that spread chikungunya, dengue, and Zika are aggressive daytime biters. They can also bite at night. Mosquitoes become infected when they feed on a person already infected with the virus. Infected mosquitoes can then spread the virus to other people through bites. (CDC, 2015). ${ }^{1}$

In Latin America, until 2014, dengue (DENV) was the only virus transmitted significantly by Aedes spp. ${ }^{2}$ unfortunately since that year, chikungunya (CHIKV) arrived as a relevant secondary arboviral disease, with the possibility of cocirculation in endemic zones as well even of co-infections. ${ }^{2 \& 3}$ Nevertheless, after more than a year of co-circulation of both arboviruses, there has been a deficiency of reports of such co-infections in the area. ${ }^{3}$ In addition to this during May 2015 first cases of infection due to Zika virus (ZIKV) were described in Brazil. ${ }^{4}$

A mother previously infected with Zika virus close the time of delivery can pass on the virus to her newborn around the time of birth, but this is rare. It is possible that Zika virus could be passed from mother to fetus during pregnancy.
This mode of transmission is being investigated. To date, there are no reports of infants getting Zika virus through breastfeeding. Because of the benefits of breastfeeding, mothers are encouraged to breastfeed even in areas where Zika virus is found (CDC, 2015) ${ }^{1}$.

The most common symptoms of Zika virus disease are fever, rash, joint pain, and conjunctivitis (red eyes). The illness is usually mild with symptoms lasting from several days to a week. Severe disease requiring hospitalization is uncommon. The incubation period ranges from 3 to 12 days. ${ }^{5}$. The disease symptoms are usually mild and last for 2 to 7 days. Infection may go unrecognized or be misdiagnosed as dengue, chikungunya or other viral infections giving fever and rash. Asymptomatic infections are common -as described with flaviviral infections such as dengue and West Nile fever- and only one in four people infected with ZIKV are believed to develop symptoms. ${ }^{6 \& 7}$

Prior to 2015, Zika virus outbreaks have occurred in areas of Africa, Southeast Asia, and the Pacific Islands. In May 2015, the Pan American Health Organization (PAHO) issued an alert regarding the first confirmed Zika virus infections in Brazil. The outbreak in Brazil led to reports of GuillainBarré syndrome and pregnant women giving birth to babies with birth defects and unfavorable pregnancy outcomes. ${ }^{8}$ Currently, outbreaks are occurring in many countries. Zika virus will continue to spread and it will be difficult to determine how the virus will spread over time. ${ }^{8}$

No locally transmitted Zika cases have been reported in the continental United States, but cases have been reported in returning travelers. Locally transmitted Zika virus has been reported in the Commonwealth of Puerto Rico. With the recent outbreaks, the number of Zika cases among travelers visiting or returning to the United States will likely increase. 


\section{International Journal of Science and Research (IJSR) \\ ISSN (Online): 2319-7064}

Index Copernicus Value (2015): 78.96 | Impact Factor (2015): 6.391

These imported cases could result in local spread of the virus in some areas of the United States. ${ }^{8}$

The probability of introduction of the virus from Brazil, Colombia, Cape Verde and Suriname to EU Overseas Countries and Territories and EU Outermost Regions, especially in South America and in the Caribbean region, has increased since the rapid risk assessment published on 25 May 2014, as the epidemic is currently spreading in South America. Considering the presence of competent vectors in these Overseas Countries, Territories and Outermost Regions, the establishment of local transmission is possible once the virus is introduced. The risk of introduction and spread of the ZIKV infections includes Madeira because of its close relationship and intense trade and travel with Brazil and Cape Verde, where ZIKV is currently circulating, and the presence of competent vectors (Aedes aegypti). ${ }^{9}$

This study will be conducted to assess knowledge amongst medical and preparatory year (Health track) students in Taif university, girls section about the Zika fever particularly because no researches was done previously about knowledge about Zika in Taif City.

\section{Subjects and Methods}

\section{Study design:}

This is a cross sectional study design.

\section{Study setting:}

Faculty of Medicine, Tail University, girls section.

\section{Study sampling and population:}

Students of medical college and preparatory year of health track section were invited to participate in the study. We classified the students into two categories, premedical (preparatory year), and medical students. Quota random sampling technique was used to choose the students. Sample of two-hundred and fifty students were participated. It included one-hundred and thirty four of medical students and one-hundred and eleven of preparatory year students.

\section{Tools of the study:}

A questionnaire prepared by the researcher containing data about age, academic class and special questions about their knowledge of Zika fever were involved.

The Zika fever knowledge questions included, What is the disease, mode of transmission, who is at risk of infection, what countries have the disease now, What can people do to prevent becoming infected with Zika, What is the treatment for Zika, How can be diagnosed, Is there a vaccine to prevent or medicine to treat, type of immunity after infection, Does Zika virus infection in pregnant women cause birth defects, Is this a new virus, Does Zika virus infection cause Guillain-Barré syndrome (GBS)? What should I do if I have Zika. Finally the source for any knowledge about Zika infection had been investigated.

The students asked to answer by know or do not know for each question. If the any student answered know for any question, she should clarify.

\section{Statistical analysis:}

The data were collected and verified by hand and then coded before entry. Statistical package for Social Science (SPSS) software version 22.0 was used for data entry and analysis. Descriptive statistics (e.g. number, percentage, arithmetic mean and standard deviation) and analytic statistics using Chi Square and $\mathrm{T}$ - test for the association and difference between categories were applied.

Total knowledge score was calculated as one mark for correct answer and zero for incorrect one. The maximum was fourteen marks for all questions. Then mean and standard deviation for total score was calculated and compared between medical students and preparatory year students using T-test.

\section{Results}

One hundred and thirty four (54.7\%) of medical students and $111(45.3 \%)$ of preparatory year students participated in the present study. The total number of participating students were 245 (Fig. 1).

Table (1) shows the knowledge of medical and preparatory year students about Zika Fever Disease; definition, symptoms, mode of transmission and at risk individuals. Regarding knowledge about what is the disease? On the total level $(35.1 \%)$ knew the correct knowledge that Zika is a disease caused by Zika virus that is spread to people primarily through the bite of an infected mosquito. Some of the students mentioned that it affects the fetus of infected pregnant mothers. The percent of knowledge was significantly higher among medical students as compared to Preparatory year students $(47.0 \%$ versus $20.7 \%)(\mathrm{P}=0.000)$.

Correct knowledge about mode of transmission of infection was mentioned by $(34.7 \%)$ of students. It was (44.8\%) among medical students and (22.5\%) among preparatory year students. Most of those mentioned that Zika is transmitted through the bite of infected mosquitoes. It can also be transmitted from a pregnant mother to her fetus during pregnancy (Table 1).

About one quarter of students (24.9\%) knew who is at risk of being infected. (29.1\%) of medical students and (19.8\%) of preparatory year students mentioned that anyone who lives in or travels to an area where Zika virus is found can get it from mosquito bites.

Table (2) shows the knowledge about symptoms of Zika virus infection. It was found that $(32.2 \%)$ of students mentioned most of the symptoms of infection. The most common symptoms of Zika virus disease that mentioned were fever, rash, joint pain, or conjunctivitis (red eyes). The percent of correct knowledge was (41.8\%) among medical students and (20.7\%) among preparatory year students.

Table (2) shows how Zika viral infection being treated according to the students' knowledge. (35.5\%) mentioned that they knew the treatment. $17.1 \%$ mentioned incorrectly that they should take antiviral drugs, $18.4 \%$ mentioned that patients may be treated by symptomatic treatment and there 


\section{International Journal of Science and Research (IJSR) \\ ISSN (Online): 2319-7064 \\ Index Copernicus Value (2015): 78.96 | Impact Factor (2015): 6.391}

is no specific treatment. Table (2) shows the low knowledge of students about methods of diagnosis of Zika viral disease. Only $(9.0 \%)$ of all students in both medical and preparatory students mentioned blood test for diagnosis.

Table (3) shows the knowledge of students about methods of prevention of Zika infection. About thirty-one percent mentioned to some extent how Zika infection is prevented. The percent was $(37.3 \%)$ among medical students and $(24.3 \%)$ among preparatory year students. The main mentioned points were mosquito control and not travelling to epidemic area.

Regarding immunity after infection, only (11.8\%) of all student thought correctly that once a person has been infected, he or she is likely to be protected from future infections and the majority $(88.2 \%)$ did not know or thought incorrectly about immunity after infection (Table 3 ).

A minor percent $(9.4 \%)$ of students $(10.4 \%$ of medical students and 8.1 of preparatory year students) correctly mentioned that there is no vaccination to prevent contracting Zika infection (Table 3).

About eighty seven percent of students did not know or incorrectly know that Zika fever disease is a new infection in the world. Only $12.7 \%$ knew that zika virus infection is not a new one. (Table 3 ).

In response to a question about what you do if you contracted infection; $(33.9 \%)$ of students mentioned that they will go to hospitals asking for medical care. The percent was higher in Preparatory year students (38.7\%) as compared to medical students $(29.9 \%)$ (Table 3$)$.

Regarding knowledge about countries that have Zika fever disease now; (21.6\%) mentioned some of countries correctly $(22.4 \%$ and $20.7 \%$ of medical and preparatory year students respectively) (Table 3 ).

Table (4) shows the knowledge of students about adverse consequences of Zika infection. Most of students (64.1\%) had a good knowledge about the birth defect that could be cause by infection of pregnant mothers.

The same table shows that none of the students know if Zika infection causes Gullian Baree syndrome or no.

Table (5) shows the total mean score of knowledge of students and comparison between medical students and preparatory year students. Out of fourteen questions, the maximum number of questions that answered answered correctly was 10 . Total mean score was $3.56 \pm 2.96$. It was significantly higher among medical students $(3.92 \pm 2.97)$ as compared to preparatory year students $(3.14 \pm 2.97)$; $\mathrm{P}=$ 0.039 .

Figure (2) shows the sources of any information they know about Zika infection, It was found that $(65.7 \%)$ mentioned Social media as a source of knowledge, $(24.9 \%)$ Mentioned TV news and (9.4\%) mentioned that they depend on medical sources.

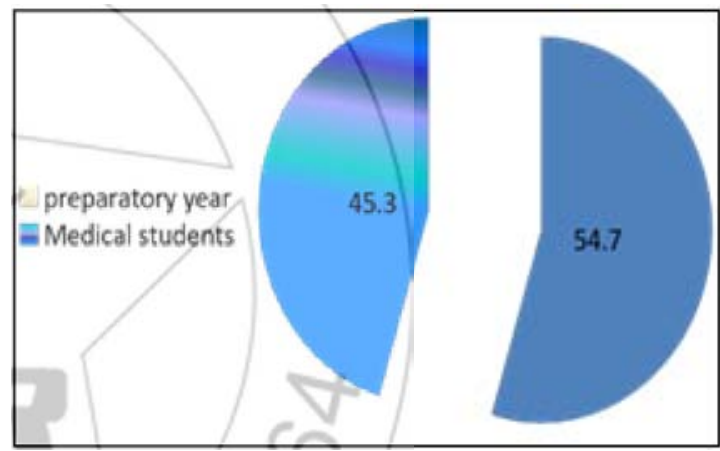

Figure 1: Distribution of the study participants

Table 1: Knowledge of students about Zika Fever Disease; definition, mode of transmission and at risk individuals

\begin{tabular}{|l|c|c|c|c|c|c|c|}
\hline Variable & Medical students & Preparatory year students & \multicolumn{2}{c|}{ total } \\
\hline & No. & $\%$ & No. & $\%$ & No. & $\%$ \\
& 134 & 54.7 & 111 & 45.3 & 245 & 100.0 \\
\hline Do you know What Zika virus disease is? & & & & & & \\
Yes & 63 & 47.0 & 23 & 20.7 & 86 & 35.1 \\
No and incorrect responses & 71 & 53.0 & 88 & 79.3 & 159 & 64.9 \\
\hline \multicolumn{7}{|c|}{} \\
\hline Do you know how is Zika transmitted? & & & & \\
Yes & 60 & 44.8 & 25 & 22.5 & 85 & 34.7 \\
No and incorrect responses & 74 & 55.2 & 86 & 77.5 & 160 & 65.3 \\
\hline Do you know who is at risk of being infected by Zika? & & & & & & \\
Yes & 39 & 29.1 & 22 & 19.8 & 61 & 24.9 \\
No and incorrect responses & 95 & 70.9 & 89 & 80.2 & 184 & 75.1 \\
\hline
\end{tabular}




\section{International Journal of Science and Research (IJSR) \\ ISSN (Online): 2319-7064 \\ Index Copernicus Value (2015): 78.96 | Impact Factor (2015): 6.391}

Table 2: Knowledge of medical students about Symptoms, treatment, and diagnosis of Zika fever Disease

\begin{tabular}{|c|c|c|c|c|c|c|}
\hline Variable & \multicolumn{2}{|c|}{ Medical students } & \multicolumn{2}{|c|}{ Preparatory year students } & \multicolumn{2}{|c|}{ total } \\
\hline & $\begin{array}{l}\text { No. } \\
134\end{array}$ & $\begin{array}{c}\% \% \\
54.7\end{array}$ & $\begin{array}{l}\text { No. } \\
111\end{array}$ & $\begin{array}{c}\% \\
45.3\end{array}$ & $\begin{array}{l}\text { No. } \\
245\end{array}$ & $\begin{array}{c}\% \\
100.0\end{array}$ \\
\hline $\begin{array}{l}\text { Do you know the symptoms of Zika fever disease? } \\
\text { - Yes } \\
\text { - No and incorrect responses }\end{array}$ & $\begin{array}{l}56 \\
78\end{array}$ & $\begin{array}{l}41.8 \\
58.2\end{array}$ & $\begin{array}{l}23 \\
88\end{array}$ & $\begin{array}{l}20.7 \\
79.3\end{array}$ & $\begin{array}{c}79 \\
166\end{array}$ & $\begin{array}{l}32.2 \\
67.8\end{array}$ \\
\hline $\begin{array}{l}\text { Do you know how is Zika fever disease is treated? } \\
\text { - } \quad \text { Yes } \\
\text { - } \\
\text { - } \text { If yes: } \\
\text { - Symptomatic treatment } \\
\text { antiviral }\end{array}$ & $\begin{array}{l}46 \\
88 \\
26 \\
20\end{array}$ & $\begin{array}{l}34.3 \\
85.7 \\
19.4 \\
14.9\end{array}$ & $\begin{array}{l}41 \\
70\end{array}$ & $\begin{array}{l}36.9 \\
63.1 \\
17.1 \\
19.8\end{array}$ & $\begin{array}{c}87 \\
158\end{array}$ & $\begin{array}{l}35.5 \\
64.5 \\
18.1 \\
17.1\end{array}$ \\
\hline $\begin{array}{l}\text { Do you know how is Zika Fever Disease diagnosed? } \\
\text { - Yes } \\
\text { - No }\end{array}$ & $\begin{array}{c}12 \\
122\end{array}$ & $\begin{array}{c}9.0 \\
91.0\end{array}$ & $\begin{array}{c}10 \\
101\end{array}$ & $\begin{array}{c}9.0 \\
91.0\end{array}$ & $\begin{array}{c}22 \\
223\end{array}$ & $\begin{array}{c}9.0 \\
91.0\end{array}$ \\
\hline
\end{tabular}

Table 3: Knowledge of students about prevention of Zika fever Disease

\begin{tabular}{|c|c|c|c|c|c|c|}
\hline Variable & Medice & udents & Preparato & students & & \\
\hline & $\begin{array}{l}\text { No. } \\
134\end{array}$ & $\%$ & $\begin{array}{l}\text { No. } \\
111 \\
\end{array}$ & $\%$ & $\begin{array}{l}\text { No. } \\
245\end{array}$ & $\%$ \\
\hline $\begin{array}{l}\text { Do you know how Zika fever disease prevented is? } \\
\text { - Yes } \\
\text { - No }\end{array}$ & $\begin{array}{l}50 \\
84 \\
\end{array}$ & $\begin{array}{l}37.3 \\
62.8 \\
\end{array}$ & $\begin{array}{l}27 \\
84 \\
\end{array}$ & $\begin{array}{l}24.3 \\
75.7 \\
\end{array}$ & $\begin{array}{c}77 \\
168 \\
\end{array}$ & $\begin{array}{l}31.4 \\
68.6 \\
\end{array}$ \\
\hline $\begin{array}{l}\text { Are you immune for life if infected? } \\
\qquad \quad \text { Yes } \\
\bullet \quad \text { No\& Do not know }\end{array}$ & $\begin{array}{c}16 \\
118 \\
\end{array}$ & $\begin{array}{l}11.9 \\
88.1 \\
\end{array}$ & $\begin{array}{l}13 \\
98 \\
\end{array}$ & $\begin{array}{l}11.7 \\
88.3 \\
\end{array}$ & $\begin{array}{c}29 \\
216 \\
\end{array}$ & $\begin{array}{l}11.8 \\
88.2 \\
\end{array}$ \\
\hline $\begin{array}{l}\text { Is there a vaccine for Zika virus diseases? } \\
\text { - incorrec) and don't know } \\
\text { - Correct }\end{array}$ & $\begin{array}{c}120 \\
14\end{array}$ & $\begin{array}{l}89.6 \\
10.4\end{array}$ & $\begin{array}{c}102 \\
9\end{array}$ & $\begin{array}{c}91.9 \\
8.1\end{array}$ & $\begin{array}{c}222 \\
23\end{array}$ & $\begin{array}{c}90.6 \\
9.4\end{array}$ \\
\hline $\begin{array}{l}\text { Is zika fever disease is a new disease? } \\
-\quad \text { Correct } \\
\text { - Incorrect and do not know }\end{array}$ & $\begin{array}{c}16 \\
118 \\
\end{array}$ & $\begin{array}{l}11.9 \\
88.1\end{array}$ & $\begin{array}{l}15 \\
96\end{array}$ & $\begin{array}{l}13.5 \\
86.5\end{array}$ & $\begin{array}{c}31 \\
214 \\
\end{array}$ & $\begin{array}{l}12.7 \\
87.3\end{array}$ \\
\hline $\begin{array}{l}\text { Do you know what should you do if you have Zika Fever Disease? } \\
\text { - Yes } \\
\text { - No }\end{array}$ & $\begin{array}{l}40 \\
94\end{array}$ & $\begin{array}{l}29.9 \\
70.1\end{array}$ & $\begin{array}{l}43 \\
68 \\
\end{array}$ & $\begin{array}{l}38.7 \\
61.3 \\
\end{array}$ & $\begin{array}{c}83 \\
162 \\
\end{array}$ & $\begin{array}{l}33.9 \\
66.1\end{array}$ \\
\hline $\begin{array}{l}\text { Do you know what countries have Zika fever disease now? } \\
\qquad \quad \text { Yes } \\
\bullet \quad \text { No }\end{array}$ & $\begin{array}{c}30 \\
104 \\
\end{array}$ & $\begin{array}{l}22.4 \\
77.6 \\
\end{array}$ & $\begin{array}{l}23 \\
88 \\
\end{array}$ & $\begin{array}{l}20.7 \\
79.3 \\
\end{array}$ & $\begin{array}{c}53 \\
192 \\
\end{array}$ & $\begin{array}{l}21.6 \\
78.4 \\
\end{array}$ \\
\hline
\end{tabular}

Table 4: Knowledge of students about adverse consequences of Zika fever Disease

\begin{tabular}{|c|c|c|c|c|c|c|}
\hline \multirow[t]{2}{*}{ Variable } & \multicolumn{2}{|c|}{ Medical students } & \multicolumn{2}{|c|}{$\begin{array}{c}\text { Preparatory year } \\
\text { students }\end{array}$} & \multicolumn{2}{|c|}{ total } \\
\hline & $\begin{array}{l}\text { No. } \\
134 \\
\end{array}$ & & $\begin{array}{l}\text { NO. } \\
111 \\
\end{array}$ & & $\begin{array}{l}\text { NO. } \\
245\end{array}$ & \\
\hline $\begin{array}{l}\text { Does Zika virus infection in pregnant women cause birth defects? } \\
\text { - Yes } \\
\text { - No }\end{array}$ & $\begin{array}{l}83 \\
51\end{array}$ & $\begin{array}{l}61.9 \\
38.1\end{array}$ & $\begin{array}{l}74 \\
37\end{array}$ & $\begin{array}{l}66.7 \\
33.3\end{array}$ & $\begin{array}{c}157 \\
88\end{array}$ & $\begin{array}{l}64.1 \\
35.9\end{array}$ \\
\hline $\begin{array}{l}\text { Does Zika virus infection causes Gullain- Barre syndrome (GBS)? } \\
\text { - Yes } \\
\text { - No \&Do not know }\end{array}$ & $\begin{array}{c}0 \\
134\end{array}$ & $\begin{array}{c}0.00 \\
100.0\end{array}$ & $\begin{array}{c}0 \\
111 \\
\end{array}$ & $\begin{array}{c}0.00 \\
100.0\end{array}$ & $\begin{array}{c}0 \\
245\end{array}$ & $\begin{array}{c}0.00 \\
100.0\end{array}$ \\
\hline
\end{tabular}

Table 5: Comparison of total score of knowledge about Zika Virus infection between medical students and preparatory

\begin{tabular}{|c|c|c|c|c|}
\hline Variable & $\begin{array}{c}\text { Medical } \\
\text { students }\end{array}$ & $\begin{array}{c}\text { Preparatory } \\
\text { year } \\
\text { students }\end{array}$ & total & \\
\hline & NO. & No. & No. & T test \\
& 134 & 111 & 245 & \\
\hline Minimum & 0 & 0 & 0 & $\mathrm{P}=0.039$ \\
Maximum & 10 & 10 & 10 & \\
Mean \pm SD & $3.92 \pm 2.99$ & $3.14 \pm 2.87$ & $3.56 \pm 2.96$ & \\
\hline
\end{tabular}

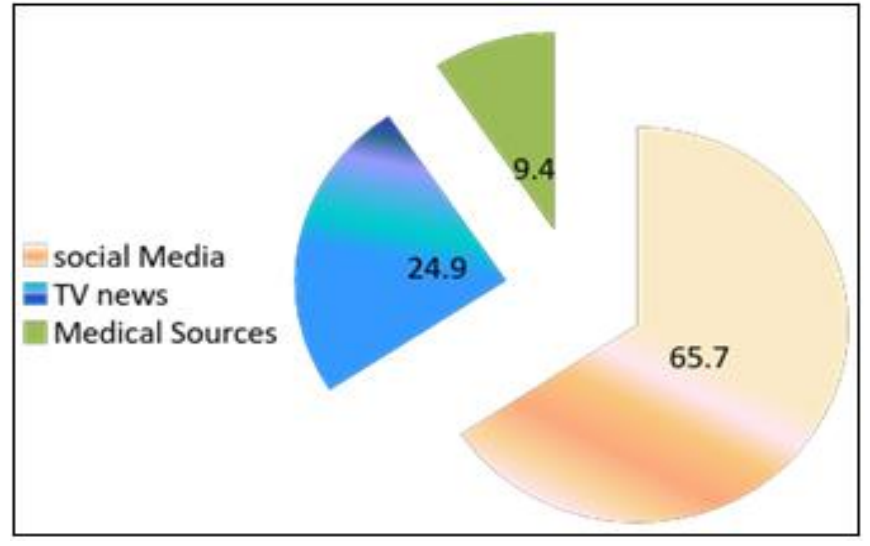

Figure 2: Source of information about Zika virus infection

Volume 6 Issue 1, January 2017 www.ijsr.net 


\section{International Journal of Science and Research (IJSR) \\ ISSN (Online): 2319-7064 \\ Index Copernicus Value (2015): 78.96 | Impact Factor (2015): 6.391}

\section{Discussion}

Table (1) displays the knowledge of medical and preparatory year students of health track about Zika Fever Disease. Regarding information about what is the disease? On the overall level only $(35.1 \%)$ recognized the correct knowledge that Zika is a disease produced by Zika virus which is transmitted to people through the bite of an infected mosquito. Some of the students said that it affects the fetus of infected pregnant mothers (table 1).

This is in accordance with CDC (2015) ${ }^{1}$ which reported that Zika is a disease caused by Zika virus which is transmitted to people mainly through the bite of an infected Aedes species mosquito, the same mosquitoes that spread Chikungunya and dengue. It can also be transmitted from a pregnant mother to her fetus during pregnancy or around the time of birth.

About one quarter of students (24.9\%) knew who is at risk of being infected. They mentioned that anyone travels to an infected area with Zika virus can get it from mosquito bites. CDC $(2015)^{1}$ also reported that anyone who lives in or travels to an area where Zika virus is found and has not already been infected with Zika virus can get it from mosquito bites.

Table (2) shows how Zika viral infection being treated according to the students' knowledge. (35.5\%) mentioned that they knew the treatment. (17.1\%) mentioned incorrectly that they should take antiviral drugs. In contrast and according to CDC guidelines (2015) ${ }^{1}$, there is no specific antiviral treatment for Zika virus. (18.4\%) of them mentioned that patients may be treated by symptomatic treatment and there is no specific treatment. This is in agreement with CDC $(2015)^{10}$ which reported that symptomatic treatment after excluding more severe conditions such as malaria, dengue, and bacterial infection is endorsed. It is significant to differentiate Zika virus infection from dengue due to severe clinical consequences in some dengue cases. Adding, cases of co-infection, Zika and dengue, could occur. There is no vaccine or specific treatment for Zika virus infection. For this reason, treatment is geared toward relieving symptoms. Symptomatic and supportive treatment includes rest and the use of acetaminophen or paracetamol to relieve fever. The use of antihistamines to control pruritus usually associated with the maculo-papular rash could be suggested. Using aspirin is not advised due to the risk of bleeding and developing Reye's syndrome in children younger than 12 years of age. The use of other nonsteroidal anti-inflammatory drugs is not advised either, since the cause of the clinical symptoms could be dengue or chikungunya, pathologies in which the use of Non-steroidal Anti-inflammatory Drugs (NSAIDs) is contraindicated. Patients should be advised to drink plenty of fluids to replenish fluid lost from sweating, vomiting and other insensible losses (CDC, 2015). ${ }^{10}$

Table (2) shows the low knowledge of students about methods of diagnosis of Zika viral disease. Only (9.0\%) of all students in both medical and preparatory students just mentioned blood test for diagnosis without any clarifications. According to PAHO/WHO (2015) ${ }^{11}$ the serological tests (ELISA or immunofluorescence) to detect specific IgM or IgG against Zika virus can be positive after 5 to 6 days following the onset of symptoms. The tests must discover an increased antibody titer in paired samples, with an interval of about two weeks. However, confirmation of positive results with plaque reduction neutralization test (PRNT) showing at least a four-fold increase in the titer of neutralizing antibodies to Zika virus is recommended.

Table (3) shows the knowledge of students about means of prevention of Zika infection. About thirty-one percent mentioned to some extent how Zika infection is prevented. The percent was (37.3\%) among medical students and $(24.3 \%)$ among preparatory year students. The main revealed points were mosquito control and not travelling to epidemic area. The students' response were deficient. PAHO/WHO (2015) ${ }^{11}$ described that to prevent infection of other persons, a Zika virus-infected patient should avoid being bitten by mosquitoes during the first week of illness (viremic phase). The patient is indorsed to stay under a bed net (treated or without insecticide), or stay in a place with intact window/door screens. In addition, physicians or health care workers who attend to Zika virus-infected patients should protect against mosquito bites by using insect repellent (IR3535 or Icaridin) and wearing long sleeves and pants.

Among prevention and control procedures, those aimed at the reduction of vector density are critical, as their effective application can prevent transmission of this virus and other mosquito borne viruses.

PAHO/WHO (2015) ${ }^{11}$ also declared that it is important to ensure antenatal care for pregnant women, including basic clinical assessment and preclinical tests according to wellknown national protocols. In areas where Zika virus is circulating, it is recommended to emphasize the need for pregnant women to take personal precautions to avoid contact with the vector (see recommendations under personal prevention measures on page 9-10 of this document). Newborns with congenital malformations must be monitored to determine any neurodevelopmental outcomes.

It is important for patients infected with dengue, chikungunya, or Zika virus to minimize contact with the vector. This measure helps prevent the spread of the virus and therefore the disease. Patients, ${ }^{12}$ their household members, and the community must be educated about the risk of transmission to others and the ways to minimize this risk by reducing vector population and human-vector contact.

Because it is impossible to completely prevent mosquito bites, the C.D.C. has advised pregnant women to avoid going to regions where Zika is being transmitted, and has advised women thinking of becoming pregnant to consult doctors before going.

Travelers to these countries are advised to avoid or minimize mosquito bites by staying in screened or air-conditioned rooms or sleeping under mosquito nets, wearing insect repellent at all times and wearing long pants, long sleeves, 


\section{International Journal of Science and Research (IJSR) \\ ISSN (Online): 2319-7064}

Index Copernicus Value (2015): 78.96 | Impact Factor (2015): 6.391

shoes and hats. (CDC, 2015). ${ }^{10}$

A minor percent $(9.4 \%)$ of students correctly mentioned that there is no vaccination to prevent contracting Zika infection (Table 3). According to CDC (2015) ${ }^{1}$ there is no vaccine against the Zika virus. Efforts to make one have just begun, and creating and testing a vaccine normally takes years and costs hundreds of millions of dollars.

Regarding immunity after infection, only (11.8\%) of all student thought correctly that once a person has been infected, he or she is likely to be protected from future infections and the majority $(88.2 \%)$ did not know or thought incorrectly about immunity after infection (Table 3). According CDC (2015) ${ }^{10}$, once a person has been infected, he or she is likely to be protected from future infections.

About eighty seven percent of students incorrectly knew that Zika fever disease is a new infection in the world. Only $12.7 \%$ knew that zika virus infection is not a new one. (Table 3). Zika virus disease is a mosquito-borne viral disease caused by Zika virus (ZIKV), a flavivirus from the Flaviviridae family and Spondweni serocomplex. The virus was first identified in 1947 in the Zika forest in Uganda in the rhesus macaque population. ${ }^{12}$ According to $\mathrm{PAHO} / \mathrm{WHO}$ $(2015)^{11}$ no outbreaks of Zika previously have been reported in tropical Africa, Southeast Asia, and the Pacific Islands. Zika virus likely will continue to spread to new areas. In May 2015, the Pan American Health Organization (PAHO) ${ }^{8}$ issued an alert regarding the first confirmed Zika virus infection in Brazil. Since that time, local transmission has been reported in many other countries and territories.

Regarding knowledge about countries that have Zika fever disease now; (21.6\%) mentioned some of countries correctly (Table 3). As of 1 December 2015, nine Member States in the Americas have confirmed autochthonous circulation of Zika virus: Brazil, Chile (on Easter Island), Colombia, El Salvador, Guatemala, Mexico, Paraguay, Suriname, and Venezuela. $^{13}$ Autochthonous circulation of Zika virus (ZIKV) in the Americas was first confirmed in February of 2014 on Easter Island, Chile, and cases were reported there up to June of 2014. In May 2015, the first autochthonous cases of Zika virus in Brazil were confirmed.

As of 1 December 2015, a total of 18 states in Brazil have confirmed autochthonous circulation: North region (Amazonas, Pará, Rondônia, Roraima, and Tocantins), Northeast region (Alagoas, Bahía, Ceará, Maranhão, Paraíba, Pernambuco, Piauí, and Rio Grande do Norte), Southeast region (Espírito Santo, Rio de Janeiro, and São Paulo), Central-West region (Mato Grosso), and South region (Paraná). ${ }^{14}$

In October 2015, the Colombia health authorities notified the detection of the first autochthonous case of Zika virus infection in the state of Bolívar. 2 To date, 26 out of 36 territorial entities in Colombia have reported autochthonous circulation of the virus. ${ }^{15}$ Additionally, in November 2015, El Salvador, Guatemala, Mexico, Paraguay, Suriname, and Venezuela each confirmed autochthonous circulation of Zika virus.
In this study, most of students (64.1\%) had a good knowledge about the birth defect that could be cause by infection of pregnant mothers (Table 4). In October 2015, the Brazil International Health Regulations (IHR) National Focal Point (NFP) notified the detection of an unusual increase in microcephaly ${ }^{16}$ cases in public and private healthcare facilities in Pernambuco state, Northeast Brazil. ${ }^{17}$ As of 30 November 2015, 1,248 cases (99.7/100,000 live births) of microcephaly ${ }^{16}$, including deaths, have been reported in 14 states of Brazil, which are under investigation. ${ }^{17}$ In 2000 , the prevalence of microcephaly in newborns in Brazil was 5.5 cases/ 100,000 live births and in 2010 it was 5.7 cases / 100,000 live births. This data demonstrates a twentyfold increase in comparison to the rate observed in previous years. The data was obtained from the Live Births Information System which captures epidemiological data related to pregnancy, births and congenital malformation, in addition to the sociodemography of the mothers. ${ }^{18}$

On 24 November 2015, the French Polynesia health authorities reported an unusual increase of central nervous system malformation in fetuses and newborns registered during 2014-2015, coinciding with the Zika virus outbreaks on the islands. Out of 17 malformations registered, 12 were fetal cerebral malformations or polymalformative syndromes, including brain lesions, and five infants were reported as having brainstem dysfunction and absence of swallowing. None of the pregnant women described clinical signs of Zika virus, but the four women that were tested were found positive by IgG serology assays for flavivirus, suggesting a possible asymptomatic Zika virus infection. Further serological investigations are ongoing. Based on the temporal correlation of these cases with the Zika epidemic, the French Polynesia health authorities hypothesize that Zika virus infection may be associated with these abnormalities if mothers are infected with the virus during the first or second trimester of pregnancy. ${ }^{18}$

On 28 November 2015, the Brazil Ministry of Health established the relationship between the increase in occurrence of microcephaly and Zika virus infection through the detection of Zika virus genome in the blood and tissue samples of a baby from the state of Pará. The newborn presented microcephaly and other congenital anomalies and died within five minutes of being born. The confirmation of the presence of the viral genome was provided by the Evandro Chagas Institute, national reference laboratory for arboviruses in Belém, Pará. According to the preliminary analysis of the investigation conducted by the Brazil health authorities, the greatest risk of microcephaly or congenital anomalies in newborns is associated with Zika virus infection in the first trimester of pregnancy. ${ }^{17}$

The same table (4) shows that none of the students know if Zika infection causes Gullian Baree syndrome or no. In July 2015, the Brazil IHR NFP reported the detection of patients with neurological syndromes with recent history of Zika virus infection, especially in the state of Bahía. Up to 13 July, 76 neurological 19 syndrome patients had been identified, of which 55\% (42/76) were confirmed as Guillain-Barré syndrome (GBS), ${ }^{20}$ out of the 76 were confirmed for other neurological syndromes, ${ }^{20}$ out of the 76 


\section{International Journal of Science and Research (IJSR) \\ ISSN (Online): 2319-7064}

Index Copernicus Value (2015): 78.96 | Impact Factor (2015): 6.391

were discarded, and 25 of the 76 remain under investigation. Among patients with GBS and based on clinical history, $62 \%(26 / 42)$ had symptoms consistent with Zika virus. ${ }^{19}$

In addition, on 25 November of 2015, the Aggeu Magalhães Research Center of the Oswaldo Cruz Foundation Institute reported that of the 224 suspected dengue patients whose samples were analyzed for Zika virus infection, ten were confirmed positive. Seven of the ten samples confirmed with Zika virus infection correspond to patients with neurological syndrome. ${ }^{20}$

During the Zika virus outbreak in French Polynesia in which 8,750 suspected cases were discovered, ${ }^{19} 74$ patients presented neurological syndromes or autoimmune syndromes following an illness with symptoms compatible with Zika virus infection in previous days. Of these, 42 were confirmed as Guillain-Barré syndrome, 37 of which had presented with a previous viral syndrome. ${ }^{17 \& 20}$ Although neither event establishes a causal relation with Zika virus, the hypothesis cannot be discarded. ${ }^{18 \& 21}$

Table (5) shows the total mean score of knowledge of students and comparison between medical students and preparatory year students. Out of fourteen questions, the maximum number of questions that answered correctly was. $^{20}$ Total mean score was $3.56 \pm 2.96$. It was significantly higher among medical students $(3.92 \pm 2.97)$ as compared to preparatory year students $(3.14 \pm 2.97) ; \mathrm{P}=0.039$.

Figure (2) shows the sources of any information they know about Zika infection, It was found that $(65.7 \%)$ mentioned Social media as a source of knowledge, $(24.9 \%)$ Mentioned TV news and (9.4\%) mentioned that they depend on medical sources.

An earlier study reported that $24.1 \%$ of physicians use social media on a daily basis to search for or explore medical information and $14 \%$ contribute to social media on a daily basis. $^{22}$ Physicians and medical students commonly use Wikipedia to obtain medical information and specify ease of use as their reason for doing so. ${ }^{23 \& 24}$ Many physicians believe that the professional use of social media allows for beneficial information exchange and is useful in caring for patients. ${ }^{23}$ Furthermore, many indicated that it was expected that they would be available through social media as their patients were also social media users. ${ }^{24 \& 25}$

\section{Conclusions and Recommendations}

The present study revealed the low level of students' knowledge about Zika virus infection. In countries without autochthonous transmission of Zika virus infection, they are recommended to strengthen event-based surveillance to detect the first cases. Based on the experiences of Brazil and Colombia, health authorities must be on alert for the emergence of clusters of rash febrile syndrome of unknown etiology (in which dengue, chikungunya, measles, rubella, and parvovirus B19 have been ruled out), and laboratory tests for Zika virus detection.

Because Zika virus outbreaks could cause additional burdens on all levels of the health care system, it is essential to improve and implement protocols and well established plans for the patient screening and treatment and increasing knowledge of medical workers.

\section{References}

[1] United States Center for Disease Control and Prevention (CDC). Zika Virus: Questions and Answers. Available at: : http://www.cdc.gov/zika/transmission/index.html (Jan 26, 2016).

[2] Alfaro-Toloza, P., Clouet-Huerta, D.E., RodríguezMorales, A.J. Chikungunya, the emerging migratory rheumatism. Lancet Infect Dis. 2015;15:510-512

[3] Schilling, S., Emmerich, P., Günther, S., SchmidtChanasit, J. Dengue and chikungunya virus co-infection in a German traveller. J Clin Virol. 2009;45:163-164.

[4] Zika Virus: A Review to Clinicians, Pinto Junior VL1, Luz K2, Parreira R3, Ferrinho P3. Acta Med Port. 2015 Nov-Dec;28(6):760-5. Epub 2015 Dec 3. Available at: http://www.ncbi.nlm.nih.gov/pubmed/26849762?dopt= Abstract

[5] Ioos S, Mallet HP, Leparc Goffart I, Gauthier V, Cardoso T, Herida M. Current Zika virus epidemiology and recent epidemics. Med Mal Infect. 2014 Jul;44(7):302-7.

[6] Musso D, Nhan T, Robin E, Roche C, Bierlaire D, Zisou $\mathrm{K}$, et al. Potential for Zika virus transmission through blood transfusion demonstrated during an outbreak in French Polynesia, November 2013 to February 2014. Euro Surveill. 2014;19(14).

[7] Duffy MR, Chen TH, Hancock WT, Powers AM, Kool JL, Lanciotti RS, et al. Zika virus outbreak on Yap Island, Federated States of Micronesia. N Engl J Med. 2009 Jun 11;360(24):2536-43.

[8] Pan American Health Organization (PAHO)/World Health Organization (WHO). Epidemiological Alert: Increase of microcephaly in the northeast of Brazil - 17 November 2015 [Internet]. 2015 [updated 2015 Nov 17; cited 2015 Nov 11]. Available from:http://www.paho.org/hq/index.php?option=com_d ocman\&task=doc_view\&Itemid=270\&gid=32285\&lang $=$ en.

[9] European Centre for Disease Prevention and Control. Zika virus infection outbreak, Brazil and the Pacific region [Internet]. ECDC; 2014 [updated 2015 May 26; cited 2015 Nov 20]. Available from: http://ecdc.europa.eu/en/publications/Publications/rapid -risk-assessment-Zika\%20virus-south-america-Brazil2015.pdf.

[10] United States Center for Disease Control and Prevention (CDC). Insect Repellent Use \& Safety. Available at: http://www.cdc.gov/westnile/faq/repellent.html (accessed 29 November 2015).

[11] PAHO/WHO 17 November 2015, Epidemiological Alert available at: http://www.paho.org/hq/index.php?option=com_docma n\&task $=$ doc_view\&Itemid $=270 \&$ gid $=32285 \&$ lang $=$ en http://reliefweb.int/report/world/epidemiological-alertneurological-syndrome-congenital-malformations-andzika-virus

[12] Balm MN, Lee CK, Lee HK, Chiu L, Koay ES, Tang JW. A diagnostic polymerase chain reaction assay for 


\section{International Journal of Science and Research (IJSR) \\ ISSN (Online): 2319-7064 \\ Index Copernicus Value (2015): 78.96 | Impact Factor (2015): 6.391}

Zika virus. J Med Virol. 2012 Sep; 84(9):1501-5.

[13]Pan American Health Organization (PAHO)/World Health Organization (WHO). Epidemiological Alert: Increase of microcephaly in the northeast of Brazil - 17 November 2015 [Internet]. 2015 [updated 2015 Nov 17; cited $2015 \quad$ Nov 11]. Available from:http://www.paho.org/hq/index.php?option=com_d ocman\&task=doc_view\&Itemid=270\&gid=32285\&lang $=$ en.

[14] The public health Emergency Operations Center report on microcephaly. Epidemiological Week 46 of 2015. Brazil Ministry of Health. Available at: http://portalsaude.saude.gov.br/index.php/cidadao/princi pal/agencia-saude/20925- ministerio-divulga-boletimepidemiologico.

[15] Epidemiological Bulletin. Colombia National Institute of Health. Epidemiological Week 46 of 2015. Available at:

http://www.ins.gov.co/boletinepidemiologico/Boletn $\% 2$ 0Epidemiolgico/2015\%20Boletin \%20epidemiologico $\%$ 20semana\%2045.pdf

[16] The public health Emergency Operations Center report on microcephaly. Epidemiological Week 47 of 2015. Brazil Ministry of Health. Available at: http://portalsaude.saude.gov.br/images/pdf/2015/novem bro/30/COES-Microcefalias--- Informe-Epidemiol-gico---SE-47---30nov2015.pdf 4. Brazil Ministry of Health. Microcephaly -

[17] Brazil Ministry of Health. Microcephaly - Ministry of Health releases epidemiological bulletin [Internet]. Available at: http://portalsaude.saude.gov.br/index.php/cidadao/princi pal/agencia-saude/20805- ministerio-da-saude-divulgaboletim-epidemiologico.

[18]European Centre for Disease Prevention and Control. Rapid risk assessment: Microcephaly in Brazil potentially linked to the Zika virus epidemic - 24 November 2015. Stockholm: ECDC; 2015. Available at:

http://ecdc.europa.eu/en/publications/Publications/zikamicrocephaly-Brazilrapid-risk-assessment-Nov2015.pdf

[19] Information provided by the Brazil International Health Regulations (IHR) National Focal Point (NFP). July 2015.

[20]Fiocruz Pernambuco answers questions about Zika virus. Agencia Fiocruz de Noticias. Available at: http://www.agencia.fiocruz.br/fiocruz-pernambucoesclarece-d $\% \mathrm{C} 3 \%$ BAvidas-sobrev\%C3\%ADrus-zika

[21]Bulletin hebdomadaire international du 5 au 11 mars 2014. $\quad \mathrm{N}^{\circ} 442$. Available at: http://www.invs.sante.fr/Publications-et-outils/Bulletinhebdomadaire-international/Tous-lesnumeros/2014/Bulletin-hebdomadaire-international-du5-au-11-mars-2014.-N-442 .

[22] McGowan BS, Wasko M, Vartabedian BS, Miller RS, Freiherr DD, Abdolrasulnia M. Understanding the Factors That Influence the Adoption and Meaningful Use of Social Media by Physicians to Share Medical Information. J Med Internet Res. 2012;14(5):e117. doi:10.2196/jmir.2138.View Article

[23] Hughes B, Joshi I, Lemonde H, Wareham J. Junior physician's use of Web 2.0 for information seeking and medical education: a qualitative study. Int $\mathrm{J}$ Med Inform. 2009;78(10):645-55.View Article

[24] Kritz M, Gschwandtner M, Hanbury A, Samwald M. Utilization and perceived problems of online medical resources and search tools among different groups of European physicians. J Med Internet Res. 2013;15(6):e122. doi:10.2196/jmir.2436.View Article

[25] Glick PL, Yamout SZ. Social media for surgeons: Understand it, embrace it, and leverage it for our profession and our patient. Surgery. 2012;52(5):9412.View Article Galarce EM, Ramanadhan S, Viswanath H. Health information seeking. In: Thompson TL, Parrott R, Nussbaum JF, editors. The Routledge handbook of health communication. Newyork: Routledge; 2011. p. 167-80. 